\title{
GRAĐANSKOPRAVNI ASPEKTI OPĆE UREDBE O ZAŠTITI OSOBNIH PODATAKA (GDPR) U PROVOĐENJU LJEKARNIČKE PRAKSE
}

\author{
$U D K: 342.721: 615$ \\ DOI: $10.31141 /$ zrpfs.2021.58.140.657 \\ Pregledni znanstveni rad \\ Primljeno: 5. 2. 2021.
}

Od samog stupanja na snagu, mogao se steći dojam da adresati dočekuju primjenu GDPR-a nepripremljeni. U radu će se istaknuti određeni problemi koji su se pojavili u usklađivanju ljekarničke prakse sa zahtjevima iz GDPR-a. Odredbe GDPR-a koje se odnose na pretpostavke valjanosti privole za obradu osobnih podataka korespondiraju sa zahtjevima za valjanost obaviještenog pristanka u suvremenim pravnim porecima. Ako se privola za upis osobnih podataka u bazu podataka vrši elektroničkim putem, treba istaknuti da istu vrijednost kao vlastoručan potpis ima samo kvalificirani elektronički potpis. Odredbe u GDPR-u koje se odnose na odgovornost za štetu, ukazuju da se odgovornost osoba uključenih u obradu osobnih podataka (voditelj i izvršitelj obrade) procjenjuje temeljem pravila o subjektivnoj odgovornosti. Postavlja se i pitanje je li podnošenje pritužbe nadzornom tijelu, odnosno nerješavanje nadležnog tijela po pritužbi, procesna pretpostavka za pokretanje postupka za naknadu štete pred nadležnim sudom.

Ključne riječi: uredba, ljekarništvo, osobni podaci, prava osobnosti, privola

\section{UVOD}

Uredba (EU) 2016/679 Europskog parlamenta i Vijeća od 27. travnja 2016. o zaštiti pojedinaca u vezi s obradom osobnih podataka i o slobodnom kretanju takvih podataka te o stavljanju izvan snage Direktive 95/46/EZ (Opća uredba o zaštiti podataka $)^{2}$ stupila je na snagu 25. svibnja 2016. godine, a primjenjuje se od 25 . svibnja 2018. godine. Uredba je u cijelosti obvezujuća i izravno se primjenjuje u svim državama članicama Europske unije. ${ }^{3}$ Republika Hrvatska 27. travnja 2018.

1 Dr. sc. Davorin Pichler, docent na Katedri za građanskopravne i obiteljskopravne znanosti Pravnog fakulteta u Osijeku, Sveučilišta J. J. Strossmayera u Osijeku; dpichler@pravos.hr

2 Uredba (EU) 2016/679 Europskog parlamenta i Vijeća od 27. travnja 2016. o zaštiti pojedinaca $\mathrm{u}$ vezi s obradom osobnih podataka i o slobodnom kretanju takvih podataka te o stavljanju izvan snage Direktive 95/46/EZ, SL L119/1 od 4. V. 2016., dostupno na: https://eur-lex.europa.eu/legal-content/HR/ TXT/?uri=celex\%3A32016R0679 (pristupljeno 8. svibnja 2020.), u daljnjem tekstu GDPR.

3 Čl. 99. GDPR-a. 
godine donosi Zakon o provedbi Opće uredbe o zaštiti podataka ${ }^{4}$ koji stupa na snagu također 25. svibnja 2018. godine.

Donošenje GDPR-a motivirano je potrebom zaštite pojedinaca u vezi s obradom njegovih osobnih podataka koja bi trebala poštovati njegova temeljna prava $\mathrm{i}$ slobode. Osobni podatak jest: ime, adresa, e-mail adresa, IP adresa, GPS lokacija, RFID tagova i kolačića na web-stranicama, telefonski broj, fotografija, videosnimka pojedinaca, OIB, biometrijski podatak (otisak prsta, snimka šarenice oka), genetski podatak, podatak o obrazovanju i stručnoj spremi, podaci o plaći, podaci o kreditnom zaduženju, podaci o računima u banci, podaci o zdravlju, seksualnoj orijentaciji, glas i mnogi drugi podaci koji se odnose na pojedinca čiji je identitet utvrđen ili se može utvrditi. ${ }^{5}$ Ovako nabrojani osobni podaci, u stvari, predstavljaju proširenu listu prava osobnosti utvrđenih čl. 19. Zakona o obveznim odnosima. ${ }^{6}$ ${ }^{7}$ Donošenje ZPOUZP-a motivirano je potrebom osiguranja provedbe GDPR-a i u tom smislu ZPOUZP uređuje ustrojstvo tijela nadležnog za praćenje primjene GDPR-a, osiguranje sredstava za njegov rad, postupanje nadležnih tijela, izricanje upravnih novčanih kazni i prekršaja.

Ljekarništvo u Republici Hrvatskoj predstavlja dio zdravstvene djelatnosti od interesa za Republiku Hrvatsku koja se obavlja kao javna služba i čiji način organizacije i provođenja uređuje Zakon o ljekarništvu. ${ }^{8,9}$

Kao što je navedeno, primjena GDPR-a u Republici Hrvatskoj započela je 25. V. 2018. godine. Međutim, iako je njena primjena najavljena, od samog stupanja na snagu 25. V. 2016. godine, mogao se steći dojam da adresati dočekuju primjenu GDPR-a nepripremljeni. Za to ne bi trebalo biti opravdanja s obzirom na dovoljno vremena za prilagodbu poslovne prakse, iako je priprema primjene nove regulative kompliciran postupak. Možda je najakutnije problem izražen upravo u ljekarničkoj djelatnosti, zbog njene opsežnosti, društvenog značaja i činjenice da su zdravstveni podaci klasificirani kao posebno osjetljivi, te će zbog toga ustanove i tvrtke koje obrađuju podatke o zdravlju biti pod posebnom paskom nadzornog tijela. ${ }^{10}$ Treba, međutim, reći i da su ponuđena rješenja u poslovnoj praksi iznenadila svojom

4 Zakon o provedbi Opće uredbe o zaštiti podataka, Narodne novine, br. 42/18, u daljnjem tekstu ZPOUZP.

5 Čl. 4. toč. 1. GDPR-a. ZOO.

6 Zakon o obveznim odnosima, Narodne novine, br. 35/05, 41/08, 125/11, 78/15, u daljnjem tekstu

7 Hrvatski zakonodavac je u čl. 19. ZOO-a nabrojao prava osobnosti fizičkih i pravnih osoba (život, tjelesno i duševno zdravlje, ugled, čast, dostojanstvo, ime, privatnost osobnog i obiteljskog života, sloboda i dr.). Zakonodavac je ispravno postupio ostavljajući listu prava osobnosti otvorenom. U teoriji o pravima osobnosti naglašava se da su prava osobnosti „u fazi stvaranja”. Lista prava osobnosti popunjava se ovisno o razvoju kulture i pravne svijesti društva. Na tu listu može biti dodano neko novo pravo osobnosti kada njegov sadržaj i granice budu utvrđene sudskom praksom. Klarić, P., Vedriš, M., Građansko pravo, Narodne novine, Zagreb, 2006., str. 106.

8 Zakon o ljekarništvu, Narodne novine, br. 121/03, 142/06, 35/08, 117/08, u daljnjem tekstu ZOLJ.

9 Osim opskrbe lijekovima i medicinskim proizvodima, ljekarnička djelatnost uključuje i opskrbu homeopatskim proizvodima, dječjom hranom i dijetetskim proizvodima, kozmetičkim i drugim sredstvima za zaštitu zdravlja. Čl. 2. i 5. ZOLJ-a.

10 Nadzorno tijelo jest Agencija za zaštitu osobnih podataka. Čl. 4. st. 1. ZPOUZP-a. 
praktičnošću i sposobnosti da se odgovori na probleme u primjeni GDPR-a. U tom smislu, u radu će se istaknuti određeni problemi koji su se pojavili u usklađivanju ljekarničke prakse sa zahtjevima iz GDPR-a i ZPOUZP-a. Naglasit će se određeni građanskopravni instituti, u okviru GDPR-a, primjena kojih može izazvati određene nedoumice u praksi. Osobni podaci, kao objekt zaštite GDPR-a, predstavljaju i sadržaj prava osobnosti kojima se zaštita pruža temeljem ZOO-a. Također, problematizirat će se pitanje davanja privole za korištenje osobnih podataka elektroničkim putem u ljekarničkoj poslovnoj praksi. Odredbe GDPR-a koje se odnose na odgovornost za štetu nametnule su potrebu da se u radu analizira vrsta primijenjene odgovornosti za štetu. Ukazat će se i na odredbe u GDPR-u o procesnim pretpostavkama za pokretanje postupka za naknadu štete pred nadležnim sudovima.

\section{PRAVA OSOBNOSTI}

Objekt zaštite GDPR-a jesu osobni podaci pojedinaca. Kako je spomenuto, upada u oči koincidiranje sadržaja osobnih podataka sa sadržajem prava osobnosti, prije svega prava na privatnost osobnog i obiteljskog života utvrđenog čl. 19. ZOO-a.

\subsection{Pravo na privatnost}

Temeljni izvor prava osobnosti predstavlja čl. 22. st. 1. Ustava Republike Hrvatske ${ }^{11}$ kojim se jamči nepovredivost osobnosti čovjeka. Pravo na privatnost, kao emanaciju općeg osobnog prava, ${ }^{12}$ Ustav RH priznaje kada određuje da se svakom jamči sigurnost $i$ tajnost osobnih podataka. ${ }^{13}$ Pravna teorija određuje da je pravo na privatnost pravo osobe da svoj privatni, obiteljski i kućni život vodi zasebno i nezavisno od drugih i ograđujući se od tuđeg neovlaštenog zadiranja, prije svega, drugih osoba, javnosti ili javne vlasti. Promatrano sa strane drugih osoba i tijela vlasti, ono predstavlja svačiju dužnost poštovati tuđu privatnost. ${ }^{14}$ Za poštovanje privatne sfere svake osobe od prvorazrednog je značaja očuvanje tajnosti njezinih osobnih podataka i individualnih komunikacija. U tom smislu, osobni podaci neke osobe mogu se prikupljati, obrađivati i koristiti jedino uz njezinu privolu, a bez njezine privole jedino pod pretpostavkama određenima zakonom, a i tada samo kada je to „u demokratskom društvu nužno radi zaštite interesa državne sigurnosti,

11 Ustav Republike Hrvatske, Narodne novine, br. 56/90, 135/97, 8/98, 113/00, 124/00, 28/01, 41/01, 55/01, 76/10, 85/10, 05/14, u daljnjem tekstu Ustav RH.

12 Gavella, N., Osobna prava, Pravni fakultet, Zagreb, 2000., str. 18.

13 Čl. 37. st. 1. Ustava RH.

14 U tom smislu, pravo na privatnost predstavlja osobno neimovinsko pravo koje daje apsolutnu i potpunu privatnu pravnu vlast u odnosu na vođenje vlastitog života i ovlast da se svakoga isključi od protupravnog zadiranja u nj. Gavella, N., op. cit. (bilj. 11), str. 211-212. 
Doc. dr. sc. Davorin Pichler: Građanskopravni aspekti Opće uredbe o zaštiti osobnih podataka (GDPR) u... Zbornik radova Pravnog fakulteta u Splitu, god. 58, 2/2021, str. 657-673

javnog reda i mira ili gospodarske dobrobiti zemlje, te radi sprečavanja nereda ili zločina, radi zaštite zdravlja ili morala ili radi zaštite prava i sloboda drugih“. ${ }^{15} 1617$

\subsection{Pravo na vlastiti lik}

Predmet prava na privatnost $\mathrm{s}$ vremenom se širio tako da se danas u pravu na privatnost vidi pravo koje pripada svakom pojedincu, ovlašćujući ga na zaštitu svega od čega se sastoji osobni život neke osobe, pa je širenjem sadržaja prava na privatnost, ono apsorbiralo i neka prava osobnosti koja su do tada postojala pored usko shvaćenog prava na privatnost. Tako je shvaćeno pravo na privatnost obuhvatilo i pravo na čast i ugled, pravo na tajnost pisama i drugih osobnih zapisa, a i pravo na vlastiti lik. ${ }^{18}$

Pravo na vlastiti lik jest zasebno osobno pravo koje ovlašćuje osobu da po svojoj volji odlučuje o objavljivanju, izlaganju i iskorištavanju svojega lika materijaliziranog u nekoj slici u šrem smislu (fotografiji, filmu i sl.), te da svakoga drugoga od toga isključi. ${ }^{19}$ Sadržaj prava na vlastiti lik jesu ovlasti osobe glede objavljivanja, prikazivanja i uporaba slike (u širem smislu) u kojoj je njezin lik materijaliziran. Zahvaljujući tome što je prevladalo shvaćanje da je pravo na vlastiti lik podvrsta prava na privatnost, jamstvo privatnosti iz suvremenih pravnih poredaka djeluje ujedno i kao jamstvo prava na vlastiti lik. To je od izuzetnog značaja u suvremenom društvu, jer je tehnički i tehnološki razvoj otvorio brojne mogućnosti materijaliziranja nečijeg lika i manipuliranja stvorenom slikom osobe, a to je opet omogućilo zlouporabu od strane trećih osoba ali i javne vlasti. ${ }^{20} \mathrm{U}$ tom smislu, važno je napomenuti da GDPR određuje „biometrijske podatke“ kao „osobne podatke dobivene posebnom tehničkom obradom u vezi s fizičkim obilježjima, fiziološkim obilježjima ili obilježjima ponašanja pojedinaca koja omogućuju ili

15 Čl. 8. st. 2. Europske konvencije za zaštitu ljudskih prava i temeljnih sloboda, Narodne novine, Međunarodni ugovori, br. 18/97, 6/99, 14/02, 13/03, 9/05, 1/06, 2/10, u daljnjem tekstu Konvencija.

16 Javnoj vlasti u pravilu nije dopušteno da osobne podatke registrira i rabi u bilo koju drugu svrhu od one za koju ih je dobila. Međutim, temeljem citiranog stavka Konvencije upotrebu osobnih podataka od strane javne vlasti treba prosuđivati u kontekstu okolnosti slučaja. Tako je u predmetu Leander v. Sweden, Europski sud za ljudska prava otkrivanje osobnih podataka o zdravlju osobe u postupku pred sudom (podaci o stanju zdravlja osobe, s obzirom na HIV) ocijenio kao povredu jamstva iz čl. 8. Konvencije, ali zahtijevanje i zapljenu medicinske dokumentacije i njezino uključivanje u spis, nije ocijenio kao povredu tog jamstva. Gavella, N., „Povreda prava na privatnost, posebno na vlastiti lik, glas, osobne zapise i pisma“", u: Alaburić, V., Gavella, N., Baretić, M., Klarić, P. (ur.), Nikšić, S., Crnić, I., Dika, M., Miladin, P., Odgovornost za neimovinsku štetu zbog povrede prava osobnosti, Narodne novine, Zagreb, 2006., str. 92.

17 Treba istaknuti da se zaštita temeljnih prava usmjerena na osobne podatke u Europi ne oslanja samo na zakone EU-a već i na zaštitu od strane Europskog suda za ljudska prava. Working Document 01/2016 on the justification of interferences with the fundamental rights to privacy and data protection through surveillance measures when transferring personal data (European Essential Guarantees), dostupno na: file:///E:/back-up-15.6.2016/ /backup\%20nakon\%20natjecaja/nakonH/backup-stick\%20posao/GDPR/ wp237_en.pdf (pristupljeno 8. svibnja 2020.).

18 Gavella, N., op. cit. (bilj. 11), str. 251-252.

19 Ibid.

20 Gavella, N., op. cit. (bilj. 15), str. 121. 
potvrđuju jedinstvenu identifikaciju tog pojedinca, kao što su fotografije lica ili daktiloskopski podaci.“21 22 Iz navedene definicije može se zaključiti da biometrijski podaci predstavljaju komplement sadržaja prava na vlastiti lik. ${ }^{23}$

Svakako da je osiguravanje odnosa povjerenja pacijenata i zaštita osobnih podataka i do sada predstavljalo značajan problem u ljekarničkoj djelatnosti, međutim, stupanjem na snagu GDPR-a pooštravaju se pravila koja se odnose na prikupljanje i obradu osobnih podataka. Budući da se ljekarnici, u obavljanju djelatnosti, koriste širokim skupom osobnih podataka, koji ujedno predstavljaju sadržaj prava osobnosti, istaknut će se određene obveze koje temeljem odredbi GDPR-a nastaju u obavljanju ljekarničke prakse.

\section{PRIKUPLJANJE, OBRADA I ZAŠTITA OSOBNIH PODATAKA U LJEKARNIŠTVU}

Ljekarne u svakodnevnom radu imaju uvid u osobne podatke pacijenata. Zbog toga je potrebno da obraćaju pozornost da isti ne postanu dostupni trećim osobama, odnosno da ne dođe do slučajnog i nezakonitog uništenja, gubitka, izmjene, neovlaštenog otkrivanja ili pristupa osobnim podacima koji su preneseni, pohranjeni ili na drugi način obrađivani. ${ }^{24} \mathrm{U}$ odnosu na prikupljanje osobnih podataka razlikujemo dva načina postupanja u ljekarništvu, ovisno o vrsti usluga koje se provode.

\subsection{Usluge od javnog interesa}

Prema GDPR-u, osobni podaci koji se odnose na zdravlje obuhvaćaju sve podatke vezane uz zdravstveno stanje ispitanika, a koji otkrivaju informacije u vezi s prijašnjim, trenutačnim ili budućim fizičkim ili mentalnim zdravstvenim stanjem ispitanika. To uključuje informacije o pojedincu prikupljene pri njegovoj registraciji tijekom pružanja zdravstvenih usluga, broj, simbol ili oznaku koji su mu dodijeljeni radi njegove jedinstvene identifikacije za zdravstvene svrhe, informacije izvedene iz testiranja ili ispitivanja dijela tijela ili tjelesne tvari (među ostalim, iz genetskih podataka i bioloških uzoraka), kao i sve informacije o bolesti, invalidnosti, riziku od bolesti, medicinskoj povijesti i drugom. ${ }^{25}$ Treba razumjeti da se u ljekarnama prikupljaju oni podaci bez kojih ne bi bilo moguće pružiti ljekarničku skrb te su to,

21 Čl. 4. st. 1. toč. 14. GDPR-a.

22 Identitet predstavlja ukupnost nepromjenjivih obilježja koja čine određenu osobu, a prema kojima se ona može razlikovati od svih drugih. Biometrija je znanost o postupcima za prepoznavanje ljudi na temelju jednog ili više tjelesnih obilježja. U ta obilježja spadaju: glas, hod, izgled lica, šarenica i mrežnica oka, otisci papilarnih linija, genotip. Radmilović, Ž. „Biometrijska identifikacija“, Policija i sigurnost, Vol. 17, No. 3-4, Zagreb, str. 161-165.

23 O problematici prikupljanja biometrijskih podataka vidi više infra.

24 Čl. 4. st. 1. toč. 12. GDPR-a.

25 Recital 35. GDPR-a. 
kako navodi GDPR, slučajevi opravdani javnim interesom, koji imaju zdravstvenu svrhu. Njihovo prikupljanje ne može biti ograničeno te za takve obrade nije potrebna privola ispitanika. ${ }^{26}$

Međutim, kako je navedeno, GDPR i ZPOUZP pooštravaju pravila koja se odnose na prikupljanje osobnih podataka. $\mathrm{U}$ tom smislu, treba ukazati na odredbe čl. 25. - 32. ZPOUZP-a koje se odnose na obradu osobnih podataka putem videonadzora. Ljekarnička djelatnost zainteresirana je za ugradnju i korištenje videonadzora iz više opravdanih razloga. Najvažniji je, svakako, prevencija kriminaliteta povezanog sa zloupotrebom opojnih sredstva. U tom smislu, potrebno je da prilikom instalacije, upravljanja i korištenja sustava videonadzora ljekarne vode računa o okolnosti da prikupljanje i obrada biometrijskih podataka putem videonadzora moraju biti usklađeni s odredbama GDPR-a i ZPOUZP-a kao i s odredbama Zakona o zaštiti na radu ${ }^{27}$ kao posebnog propisa. Pri tome, čl. 43. ZZR-a nadzorne uređaje (audio i videouređaje) određuje kao sredstva zaštite na radu i, prije svega, regulira prikupljanje i obradu osobnih podataka putem nadzornih uređaja $\mathrm{u}$ odnosu na zaposlenike poslodavca. ${ }^{28} \mathrm{U}$ odnosu na obradu osobnih podataka putem videonadzora ZPOUZP određuje da je voditelj ili izvršitelj obrade ${ }^{29}$ dužan označiti da je objekt ili pojedina prostorija pod videonadzorom, a oznaka mora biti vidljiva najkasnije prilikom ulaska u perimetar snimanja. ${ }^{30}$ Također, sustav pohrane podataka prikupljenih videonadzorom mora biti podešen tako da se podaci čuvaju najdulje šest mjeseci za sve jedinice (pojedine ljekarne). Sustav zapisa mora biti automatiziran za evidentiranje pristupa snimkama video nadzora koji će sadržavati vrijeme i mjesto pristupa, kao i oznaku osoba koje su izvršile pristup podacima prikupljenima putem videonadzora. ${ }^{31}$ Snimke dobivene putem videonadzora čuvaju

26 Treba naglasiti i to da su ljekarne i do sada vodile posebnu brigu o zaštiti osobnih podataka te da su se podaci o zdravstvenom stanju pacijenta oduvijek čuvali kao posebno povjerljivi i podlijegali su pravilima čuvanja profesionalne tajne koja je posebno uređena Zakonom o zdravstvenoj zaštiti, zakonom o ljekarništvu, Kodeksom ljekarničke etike i deontologije, i nizom pravilnika koji proizlaze iz navedenih propisa. Grundler Bencarić, A., GDPR: Trebaju li pacijenti ljekarnicima dati privolu za osobne podatke?, dostupno na: https://www.adiva.hr/adiva-ljekarne/rijec-farmaceuta/gdpr-trebaju-li-pacijentiljekarnicima-dati- privolu-za-osobne-podatke/ (pristupljeno 8. svibnja 2020.). ZZR.

27 Zakon o zaštiti na radu, Narodne novine, br. 71/14, 118/14, 154/14, 94/18, 96/18, u daljnjem tekstu

28 Tako se zabranjuje instalacija nadzornih uređaja u prostorijama za osobnu higijenu i presvlačenje radnika, prilikom zapošljavanja poslodavac mora obavijestiti radnika da ce biti nadziran audio ili videouređajima, poslodavac je dužan osigurati da snimljeni materijali ne budu dostupni neovlaštenim osobama. Cl. 43. ZZR-a.

29 Voditelj obrade jest fizička ili pravna osoba, tijelo javne vlasti, agencija ili drugo tijelo koje samo ili zajedno s drugima određuje svrhe i sredstva obrade osobnih podataka. Izvršitelj je obrade fizička ili pravna osoba, tijelo javne vlasti, agencija ili drugo tijelo koje obrađuje osobne podatke u ime voditelja obrade. Čl. 4. toč. 7. i 8. GDPR-a.

30 Obavijest mora sadržavati i podatke o voditelju obrade i podatke za kontakt putem kojih ispitanik može ostvariti svoja prava. Čl. 27. ZPOUZP-a.

31 Čl. 27. ZPOUZP-a. 
se najviše šest mjeseci, osim ako je drugim zakonom propisan dulji rok ili su dokaz u sudskom, upravnom, arbitražnom ili drugom postupku. ${ }^{32} 33$

\subsection{Marketinške aktivnosti}

Novost u ljekarnama, kao i u većini uslužnih djelatnosti, odnosi se na marketinške djelatnosti. Temeljem GDPR-a, korištenje osobnih podataka za obavijesti pacijentima o promotivnim akcijama u ljekarnama, putem elektroničke pošte ili unutar programa vjernosti, s obzirom da to nisu usluge od javnog interesa, podliježe obvezi dobivanja privole pacijenta. To znači da svi pacijenti, ako žele dobivati promotivne obavijesti, trebaju dati svoj nedvosmisleni pristanak, a imaju ga pravo povući u bilo kojem trenutku, kao i zatražiti brisanje svojih podataka iz evidencija za promotivne programe. ${ }^{34}{ }^{35} \mathrm{U}$ određenim slučajevima ljekarnici žele koristiti osobne podatke pacijenta za svrhe koje ne ulaze u kategorije zdravstvene skrbi ili tretmana. Tako će postojati tanka linija između korištenja osobnih podataka u svrhu zdravstvene skrbi i u komercijalne svrhe. Na primjer, vlasnik ljekarne želi kontaktirati pacijenta s ponudom o prodaji mjerača krvnog tlaka. Ako vlasnik ljekarne želi koristiti osobne podatke pacijenta (npr. u spomenutom slučaju - e-mail adresu pacijenta), kako bi s pacijentom komunicirao iz razloga koji nemaju veze sa svrhom zbog koje je osobni podatak (e-mail adresa) prikupljen, morat će za to pribaviti privolu pacijenta. ${ }^{36}$ Dosadašnja ljekarnička praksa, u komparativnim pravnim sustavima, ukazuje na različite oblike povreda postupanja s osobnim podacima pacijenata. Iako su konkretni podaci iz istraživanja teško dostupni, gubitak osobnih podataka pacijenata predstavljao je najčešću povredu u ljekarničkoj praksi. Također, povreda

32 Čl. 30. ZPOUZP-a.

33 Treba istaknuti da se kod poslodavaca postavilo pitanje u vezi s objavom fotografije zaposlenika. Držimo da bi privola predstavljala valjani pravni temelj. Ta privola može biti i općenita, odnosno zaposlenik može dati jednu općenitu privolu da dopušta objavu svojih fotografija sačinjenih prilikom raznih npr. team buildinga i sl. Ako se zaposlenik odbije fotografirati, jer ne želi objavu fotografija, u tom slučaju njegove fotografije ne bi se smjele objavljivati jer za njihovu objavu ne postoji neki drugi pravni temelj (npr. izvršenje ugovora, poštovanje pravnih obveza voditelja obrade itd.). Recital 42. GDPR-a navodi da se ne može smatrati da je privola dana dobrovoljno ako ispitanik nema istinski ili slobodan izbor ili ako nije u mogućnosti odbiti ili povući privolu bez posljedica. Nadalje, recital 43. GDPR-a određuje da privola kao pravni temelj može doći u pitanje u onim slučajevima gdje postoji jasna neravnoteža između ispitanika i voditelja obrade. U tom smislu, u radnom odnosu gdje je očito da postoji neravnoteža između poslodavca i zaposlenika treba posebno voditi računa o tome ovisi li izvršenje ugovora (konkretno ugovora o radu) o privoli i ako takva privola nije nužna za takvo izvršenje. Zbog toga treba zauzeti stav da bi privola zaposlenika glede objave fotografije predstavljala valjani pravni temelj, s obzirom na to da odbijanje zaposlenika da se fotografira ne bi doista trebalo imati ikakvih negativnih posljedica po njega jer njegovo odbijanje za navedenu radnju ne može ni na koji način narušiti radni odnos, niti odvijanje poslovnih procesa ovisi o toj radnji.

34 Grundler Becanić, A., op. cit. (bilj 25).

35 Pri tome, povlačenje pristanka mora biti jednostavno kao što je bilo i davanje pristanka. Svaka nemogućnost zadovoljavanja ovog uvjeta vodit će nevaljanosti danog pristanka. Wardle, N., Reissner, D., „How pharmacists can comply with GDPR“, The Pharmaceutical Journal, dostupno na: https:// www.pharmaceutical-journal.com/cpd-and-learning/learning-article/how-pharmacists-can-comply-withgdpr/20204872.article?firstPass=false (pristupljeno 8. svibnja 2020.).

36 Ibid. 
obveze da se osobni podaci ne čuvaju dulje nego je potrebno za ostvarenje svrhe radi koje se osobni podatak obrađuje, bila je češća kod velikih ljekarničkih tvrtki. ${ }^{37}$ Rizik od oštrih sankcija zbog neusklađivanja ljekarničke prakse s odredbama GDPR-a treba biti ozbiljno shvaćen kao i svaki napor da se usklađivanje postigne.

\section{DVOJBE I OTVORENA PITANJA USKLAĐIVANJA S GDPR-OM}

\subsection{Pristanak za obradu podataka}

GDPR i ZPOUZP koriste pojam ,privola“ u značenju dobrovoljnog, posebnog, informiranog i nedvosmislenog izražavanja želja ispitanika kojim on izjavom ili jasnom potvrdnom radnjom daje pristanak za obradu osobnih podataka koji se na njega odnose. ${ }^{38}$ Prema dikciji iz GDPR-a i ZPOUZP-a možemo zaključiti da pojam „privola“ treba razumijevati u značenju ,pristanka“, odnosno oblika izjave volje u kojem se izražava unutarnja volja subjekta. ${ }^{39}{ }^{40} \mathrm{U}$ tom smislu, čl. 249. ZOO-a za valjanost očitovanja volje postavlja zahtjev da volja za sklapanje ugovora mora biti učinjena slobodno i ozbiljno te da se iz izjave volje sa sigurnošću može zaključiti o njezinu postojanju, sadržaju i identitetu davatelja izjave. U tom slučaju volja za sklapanje ugovora može se izjaviti i pomoću različitih komunikacijskih sredstava. ${ }^{41}$

$\mathrm{S}$ obzirom na način i sredstva prikupljanja osobnih podataka korisnika u ljekarničkoj djelatnosti te davanja korisnikova pristanka kada se radi o uslugama koje izlaze iz opsega javnog zdravlja (npr. „osobni ljekarnik“ - usluge konzultacije uz ljekarničku skrb) od značaja je programsko rješenje koje ljekarne koriste (npr.

37 Postoje primjeri i nedopuštenih ugovornih raspolaganja osobnim podacima pacijenata. Takav je npr. slučaj kada je ljekarnička tvrtka prodala popis pacijenata trgovačkom poduzeću kako bi ono moglo ostvariti ekonomsku korist od ove osjetljive skupine osoba. Ibid.

38 Čl. 4. toč. 9. GDPR-a.

39 Klarić, P., Vedriš, M., op. cit. (bilj. 6), str. 127.

40 Treba istaknuti i da engleski tekst GDPR-a koristi pojam consent. Prevoditelj se u hrvatskom prijevodu GDPR-a odlučio za pojam ,privola“ umjesto „,pristanak“, iako potonji već postoji i ima svoje pravno značenje u hrvatskom zakonodavstvu.

41 N. Gavella smatra da je pristanak po svojoj prirodi pravni posao, iz čega proizlazi da je za valjanost pristanka potrebno da ispunjava opće pretpostavke valjanosti pravnog posla. S druge strane, P. Klarić, u skladu s određenjima iz njemačke pravne teorije, smatra da pristanak na medicinski zahvat po svojoj prirodi nije pravni posao jer nije usmjeren na imovinskopravno raspolaganje, pa prema tome može biti valjan i kada ne ispunjava opće pretpostavke valjanosti pravnog posla. Slična suprotstavljena stajališta postoje i u njemačkoj i austrijskoj pravnoj književnosti prema kojoj pristanak pacijenta nema karakter pravnog posla. Švicarsko pravo, s druge strane, pristanak oštećenog na nanošenje štete, pa tako i pristanak pacijenta, smatra jednostranim pravnim poslom. Ovo iz razloga što se u švicarskom pravu osobna dobra (život, tjelesni integritet itd.) određuju objektima građanskopravnih odnosa bez obzira na to što nemaju imovinski karakter. Zbog toga pravni subjekti i mogu raspolagati svojim osobnim dobrima temeljem pravnih poslova. Nikšić, S., Ugovor o zdravstvenoj usluzi, doktorska disertacija, Pravni fakultet, Zagreb, str. 368-373. 
ESKULAP 2000). ${ }^{42}{ }^{43}$ Ako se privola, npr. za upis osobnih podataka u bazu podataka, vrši elektroničkim putem, treba istaknuti da istu vrijednost kao vlastoručan potpis ima samo kvalificirani elektronički potpis. ${ }^{44}$ Kvalificirani elektronički potpis znači napredan elektronički potpis koji je izrađen pomoću kvalificiranih sredstava ${ }^{45} \mathrm{za}$ izradu elektroničkog potpisa i temelji se na kvalificiranom certifikatu za elektroničke potpise. Napredan elektronički potpis jest elektronički potpis koji zadovoljava određene zahtjeve. Te zahtjeve propisuje čl. 26. U-910/14 koji određuje kao napredan elektronički potpis onaj koji je na nedvojben način povezan s potpisnikom, omogućava identificiranje potpisnika, izrađen je korištenjem podacima za izradu elektroničkog potpisa koje potpisnik može, uz visoku razinu pouzdanja, koristiti pod svojom isključivom kontrolom i povezan je s njime potpisanim podacima na način da se može otkriti bilo koja naknadna izmjena podataka.

Odredbe čl. 7. GDPR-a odnose se na sadržaj i pretpostavke valjanosti privole za obradu osobnih podataka. Posebnu pažnju citirani članak obraća na dobrovoljnost

42 Ključni element sigurnosti u obradi osobnih podataka jest razvoj adekvatnog računalnog programa. Article 29 Data Protection Working Party, Statement on the 2016 action plan for the implementation of the General Data Protection Regulation (GDPR) - 442/16/ENWP236, dostupno na: https://ec.europa.eu/ newsroom/article29/item-detail.cfm?item_id=640360 (pristupljeno 8. svibnja 2020.).

43 Nova verzija programa ESKULAP 2000, koji ljekarne koriste u svom radu, sadrži niz promjena i dopuna koje osiguravaju visoku razinu zaštite osobnih podataka koja je usklađena s regulativom propisanom GDPR-om. Osim zaštite u dnevnom radu, kroz programsko rješenje, napravljena je i dodatna zaštita osobnih podatka do kojih bi mogla doći „treća“ strana, krađom računala i/ili podataka koji se nalaze u zaštitnim kopijama. Sistemska razina zaštite podataka napravljena je u dijelu arhive podataka na način da su sve arhive zaštićene kriptiranjem i neupotrebljive za „treće“ strane koje bi krađom mogle doći do arhiva. Korisnička razina zaštite napravljena je na način da se svakom korisniku mora upisati razina ovlaštenja koja mu omogućava pristup određenom skupu podataka kroz programsko rješenje (sve osobe u ljekarni neće imati istu korisničku razinu koja bi im omogućavala pristup svim opcijama u programu). Uvedena je dodatna evidencija svakog udaljenog spajanja servisa (npr. radi otklanjanja poteškoća u radu) iz kojeg se vidi svaki doticaj s podacima ljekarne. S potvrde o preuzimanju eRecepta brišu se osobni podaci pacijenta. Svaki izvoz podataka zapisuje se u tablicu i može se koristiti u slučaju istrage o tzv. „,curenju podataka“. Nova verzija programa ESKULAP 2000 Verzija 3.4.5 - početak primjene GDPR-a, dostupno na: http://www.i-s.hr/default.aspx?ContentId=802 (pristupljeno 8. svibnja 2020.).

44 Čl. 25. toč. 2. Uredbe (EU) br. 910/2014 Europskog parlamenta i Vijeća od 23. srpnja 2014. o elektroničkoj identifikaciji i uslugama povjerenja za elektroničke transakcije na unutarnjem tržištu i stavljanju izvan snage Direktive 1999/93/EZ, SL L 257/73 od 28. VIII. 2014., dostupno na: http://eurlex.europa.eu/legal-content/HR/TXT/?uri=CELEX\%3A32014R0910 (pristupljeno 8. svibnja 2020.), u daljnjem tekstu U-910/14.

45 Kvalificirana sredstva za izradu elektroničkih potpisa moraju se pomoću odgovarajućih tehničkih i postupovnih sredstava pobrinuti za to da je u razumnoj mjeri osigurana povjerljivost podataka za izradu elektroničkog potpisa koji se upotrebljavaju za izradu elektroničkog potpisa, da se podaci za izradu elektroničkog potpisa praktički mogu pojaviti samo jedanput, da se podaci za izradu elektroničkog potpisa ne mogu, uz razuman stupanj pouzdanja, iz njega izvesti, te da je elektronički potpis pouzdano zaštićen od krivotvorenja korištenjem trenutačno dostupnom tehnologijom, da zakoniti potpisnik može pouzdano zaštititi podatke za izradu elektroničkog potpisa od korištenja od strane drugih osoba. Kvalificirana sredstva za izradu elektroničkih potpisa ne smiju mijenjati podatke koji se potpisuju niti priječe prikazivanje takvih podataka potpisniku prije potpisivanja. Prilog II. U-910/14. 
i obaviještenost ispitanika/davatelja privole. ${ }^{46}{ }^{47}$ Iz toga se može zaključiti da navedene odredbe korespondiraju sa zahtjevima za valjanost obaviještenoga pristanka u suvremenim pravnim porecima.

\subsection{Odgovornost za štetu}

GDPR u čl. 82. uređuje pravo na naknadu štete i odgovornost za štetu osoba uključenih u obradu osobnih podataka. Prema dikciji spomenute odredbe možemo zaključiti da se radi o subjektivnoj (kulpoznoj) odgovornosti za štetu. Kao osobe odgovorne za štetu navode se voditelj ili izvršitelj obrade. ${ }^{48}$ Oštećeni ima pravo na naknadu materijalne i nematerijalne štete. ${ }^{49}$

\subsubsection{Obveze voditelja i izvršitelja obrade}

Voditelj obrade, odnosno ljekarna, ima temeljem GDPR-a brojne opće obveze. Tako voditelj obrade provodi odgovarajuće tehničke i organizacijske mjere kako bi osigurao i mogao dokazati da se obrada provodi u skladu s GDPR-om. Prije svega, ove mjere uključuju pseudonimizaciju ${ }^{50}$ te obradu samo osobnih podataka koji su nužni za svaku posebnu svrhu obrade. ${ }^{51}$ Navedene mjere mogu se prema potrebi preispitivati i ažurirati. U tom smislu, svaka ljekarna bi trebala izraditi politiku zaštite osobnih podataka (pravila postupanja), utvrditi potreban sigurnosni profil za arhiviranje podataka te voditi evidenciju aktivnosti obrade za određene baze podataka. Voditelj obrade koristi se izvršiteljima obrade ako jamče provedbu tehničkih i organizacijskih mjera na način da je obrada u skladu sa zahtjevima iz GDPR-a i da se njome osigurava zaštita prava ispitanika. Obrada koju provodi izvršitelj obrade uređuje se ugovorom između voditelja i izvršitelja obrade.

46 Čl. 7. GDPR-a određuje da ispitanik privolu daje u vidu pisane izjave te da zahtjev za privolu mora biti predočen na način da ga se može jasno razlučiti od drugih pitanja, u razumljivom i lako dostupnom obliku uz uporabu jasnog i jednostavnog jezika. Prije davanja privole ispitanika se mora o tome obavijestiti, a povlačenje privole mora biti jednako jednostavno kao i njezino davanje.

47 Do sada je bila uobičajena praksa za web-stranice i aplikacije da u svoje uvjete korištenja uključe izraze koji pacijentu indiciraju da klikom na prihvaćanje uvjeta, ili nastavljanjem na sljedeću stranicu, pacijent daje više različitih pristanaka. Takav pristanak više nije valjan ukoliko pacijentu nije bila dana mogućnost dati pojedinačni pristanak za svaku individualiziranu svrhu. Wardle, N., Reissner, D., op. cit. (bilj. 34).

48 Dok GDPR predviđa odgovornost svakog voditelja obrade koji je uključen u obradu, odgovornost izvršitelja obrade postoji samo u slučaju ako nije poštovao obveze iz GDPR-a koje su posebno namijenjene izvršiteljima obrade ili je djelovao izvan zakonitih uputa voditelja obrade ili protivno njima. Čl. 82. st. 2. GDPR-a.

49 Čl. 82. st. 1. GDPR-a.

50 Pseudonimizacija znači obradu osobnih podataka na način da se osobni podaci više ne mogu pripisati određenom ispitaniku bez uporabe dodatnih informacija, pod uvjetom da se takve dodatne informacije drže odvojeno te da podliježu tehničkim i organizacijskim mjerama kako bi se osiguralo da se osobni podaci ne mogu pripisati pojedincu čiji je identitet utvrđen ili se može utvrditi. Čl. 4. toč. 5. GDPR-a.

${ }_{51}$ Takve mjere, u stvari, imaju za svrhu da osobni podaci nisu automatski, bez intervencije pojedinca, dostupni neograničenom broju pojedinaca. Čl. 24-25. GDPR-a. 
Ugovorom se reguliraju predmet i trajanje obrade, priroda i svrha obrade, vrsta osobnih podataka i kategorija ispitanika te obveze i prava voditelja obrade..$^{52}$

Voditelj i izvršitelj obrade imenuju službenika za zaštitu podataka u slučajevima kada: obradu provodi tijelo javne vlasti, osnovne djelatnosti voditelja i izvršitelja obrade sastoje se od postupaka obrade koji po svojoj prirodi, opsegu i svrsi iziskuju praćenje ispitanika u velikoj mjeri, osnovne djelatnosti voditelja i izvršitelja obrade sastoje se od opsežne obrade posebnih podataka ${ }^{53}$ i podataka u vezi s kaznenim osudama i kažnjivim djelima. ${ }^{54}{ }^{55}$ Službenik za zaštitu podataka imenuje se na temelju stručnih kvalifikacija o pravu i praksama u području zaštite podataka i može biti član osoblja voditelja ili izvršitelja obrade, ali može izvršavati preuzete obveze i temeljem ugovora o djelu. ${ }^{56} 57$

\subsubsection{Pretpostavke odgovornosti za štetu}

Iz dikcije st. 3. čl. 82. GDPR-a može se zaključiti da se radi o podvrsti subjektivne odgovornosti kod koje se krivnja štetnika predmnijeva. ${ }^{58}$ Dakle, oštećeni mora dokazati štetnu radnju štetnika, štetu, uzročnu vezu, a ne i krivnju štetnika jer se ona predmnijeva. Pri tome vrijedi pravilo da se predmnijeva najniži stupanj krivnje, odnosno obična nepažnja. ${ }^{59} \mathrm{U}$ slučajevima građanskopravne odgovornosti voditelja i izvršitelja obrade radi se o sudionicima obveznih odnosa koji ispunjavaju obveze iz svoje profesionalne djelatnosti te je potrebno da pri tome postupaju s povećanom

52 Ugovorom će se posebno odrediti da izvršitelj obrade obrađuje osobne podatke samo prema zabilježenim uputama voditelja obrade, osigurava da su se osobe ovlaštene za obradu osobnih podataka obvezale na poštovanje povjerljivosti, provodi tehničke i organizacijske mjere radi osiguranja odgovarajuće razine sigurnosti (pseudonimizaciju i enkripciju osobnih podataka, osiguravanje trajne povjerljivosti, dostupnosti i otpornosti usluga obrade osobnih podataka, procjenu rizika od slučajnog ili nezakonitog uništenja, gubitka, neovlaštenog otkrivanja ili neovlaštenog pristupa osobnim podacima), briše sve osobne podatke nakon dovršetka pružanja usluga vezanih za obradu, stavlja na raspolaganje voditelju obrade sve informacije neophodne za dokazivanje poštovanja obveza utvrđenih GDPR-om. Čl. 28. GDPR-a.

53 Podaci koji otkrivaju rasno ili etničko podrijetlo, politička mišljenja, vjerska ili filozofska uvjerenja, članstvo u sindikatu te obrada genetskih podataka, biometrijskih podataka, podataka koji se odnose na zdravlje, spolni život ili seksualnu orijentaciju pojedinca. Čl. 9. GDPR-a.

${ }_{54}$ Čl. 37. GDPR-a.

55 Službenik za zaštitu podataka može imati odgovornosti za više od jednog poduzetnika. Poduzetnici mogu odlučiti da jedan službenik za zaštitu podataka obavlja poslove za njih. Ovo može olakšati teret poslovanja, posebno za manje ljekarne koje bi u suprotnom imale problema s pronalaženjem dovoljnog broja radnika koje trebaju vršiti i ulogu službenika za zaštitu podataka. Wardle, N., Reissner, D., op. cit. (bilj. 34).

56 Čl. 37. GDPR-a.

57 Obveze službenika za zaštitu podataka jesu informiranje i savjetovanje voditelja ili izvršitelja obrade te zaposlenika koji obavljaju obradu o njihovim obvezama iz GDPR-a, praćenje poštovanja GDPR-a voditelja ili izvršitelja obrade u odnosu na zaštitu osobnih podataka i osposobljavanje osoblja koje sudjeluje u postupcima obrade, pružanje savjeta u pogledu procjene učinaka na zaštitu podataka i praćenje izvršavanja GDPR-a, suradnja s nadzornim tijelom. Čl. 39. GDPR-a.

58 Voditelj obrade ili izvršitelj obrade izuzet je od odgovornosti ako dokaže da nije ni na koji način odgovoran za događaj koji je prouzročio štetu. Čl. 82. st. 3. GDPR-a.

59 S običnom nepažnjom postupa onaj štetnik koji u svom ponašanju ne upotrijebi onu pažnju koju bi upotrijebio dobar gospodarstvenik odnosno dobar domaćin. Klarić, P., Vedriš, M., op. cit. (bilj. 6), str. 598. 
pažnjom, prema pravilima struke i običajima (pažnja dobrog stručnjaka). ${ }^{60}$ Dakle, za voditelja i izvršitelja obrade utvrđuje se mjerilo njihove profesionalne pažnje temeljem dvaju kriterija: prema osobama iz njihova profesionalnog kruga i konkretnim okolnostima obrade osobnih podataka ${ }^{61} \mathrm{U}$ tom smislu, potrebno je kao kriterij uzeti pažnju iskusnog i savjesnog djelatnika iste kategorije i ranga kao onoga čije se ponašanje ocjenjuje. ${ }^{62}$ Odgovornost voditelja i/ili izvršitelja obrade je solidarna, a onaj štetnik koji podmiri cijeli iznos pretrpljene štete ima pravo na regresni zahtjev u odnosu na ostale voditelje i izvršitelje obrade. ${ }^{63} 64$

Budući da je prethodno istaknuto kako se u slučajevima građanskopravne odgovornosti voditelja i izvršitelja obrade radi o subjektivnoj odgovornosti kod koje se krivnja predmnijeva, štetnici će se moći ekskulpirati time da dokažu svoju nekrivnju ${ }^{65}$ Međutim, s obzirom na brojne istaknute obveze voditelja i izvršitelja obrade može se zaključiti da je položaj štetnika u postupku naknade štete izuzetno težak. Osim spomenutih općih obveza voditelja i izvršitelja obrade, određenih čl. 24. - 39. GDPR-a, treba istaknuti i dužnost poštovanja kodeksa ponašanja namijenjenih pružanju doprinosa ispravnoj primjeni GDPR-a. ${ }^{66}$ Osim toga, voditelj i izvršitelj obrade moraju poštovati i mehanizme certificiranja,${ }^{67}$ pečate i oznake za zaštitu podataka. Mehanizmi certificiranja uspostavljaju se u svrhu dokazivanja da su postupci obrade koje provode voditelj i izvršitelj obrade u skladu s GDPR-om. Međutim, činjenica da je voditelju ili izvršitelju obrade izdan certifikat od strane nadležnog tijela ne umanjuje odgovornost voditelja ili izvršitelja za poštovanje odredbi GDPR-a. ${ }^{68}{ }^{69}$ Također, izvršitelj obrade, u postupku naknade štete, bit će dužan dokazati i da nije povrijedio obvezu iz spomenutog ugovora kojim se uređuje obrada koju provodi izvršitelj obrade, predmet i trajanje obrade, priroda i svrha obrade, vrsta osobnih podataka i kategorija ispitanika te prava i obveze voditelja

60 Ibid.

${ }^{61}$ Klarić, P., Odštetno pravo. Narodne novine, Zagreb, 2003., str. 401.

62 Ibid.

63 Ako su voditelj ili izvršitelj obrade uključeni u istu obradu, svaki voditelj ili izvršitelj obrade trebao bi se smatrati odgovornim za cjelokupnu štetu. Međutim ako su povezani u isti sudski postupak, u skladu s pravom države članice, naknada se može raspodijeliti u skladu s odgovornošću svakog voditelja ili izvršitelja obrade za štetu prouzročenu obradom, pod uvjetom da se osigura puna i učinkovita naknada ispitaniku koji je pretrpio štetu. Svaki voditelj ili izvršitelj obrade koji je platio punu naknadu, može naknadno pokrenuti postupak za regres protiv drugih voditelja ili izvršitelja obrade. Recital 146. GDPR-a.

${ }_{64}$ Čl. 82. st. 4. i 5. GDPR-a.

65 Klarić, P., Vedriš, M., op. cit. (bilj. 6), str. 610.

66 Čl. 40. GDPR-a određuje da Udruženja i druga tijela koja predstavljaju kategorije voditelja ili izvršitelja obrade mogu izraditi kodekse ponašanja radi preciziranja primjene GDPR-a u pogledu poštene i transparentne obrade, legitimnih interesa voditelja obrade u posebnim kontekstima, prikupljanja osobnih podataka, pseudonimizacije osobnih podataka, ostvarivanja prava ispitanika, izvansudskih i drugih postupaka za rješavanje sporova između voditelja obrade i ispitanika s obzirom na obradu.

${ }^{67}$ Mehanizme certificiranja izdaju certifikacijska tijela s odgovarajućim stupnjem stručnosti iz područja zaštite podataka akreditirana od strane nadzornog tijela. Čl. 42. i 43. GDPR-a.

68 Čl. 42. GDPR-a.

69 Poštovanje odobrenog kodeksa ponašanja ili mehanizma certificiranja odobrenog od strane izvršitelja obrade može se upotrijebiti kao element u dokazivanju poštovanja obveza voditelja obrade. Recital 81. GDPR-a. 
obrade. Ovdje treba istaknuti da se takav ugovor može, u cijelosti ili djelomično, temeljiti na standardnim ugovornim klauzulama koje su dio certifikata dodijeljenog voditelju ili izvršitelju obrade. Standardne ugovorne klauzule može donijeti Agencija za zaštitu osobnih podataka ili Europska komisija. ${ }^{70} 71{ }^{72}$ Upravo zbog brojnosti obveza i teškoća s dokazivanjem njihova ispunjavanja, u cilju ekskulpacije, GDPR predlaže da bi voditelj i izvršitelj obrade trebali voditi evidenciju o aktivnostima obrade pod svojom odgovornošću radi dokazivanja sukladnosti s GDPR-om. ${ }^{73}$

Nematerijalna šteta može nastati kao posljedica građanskog delikta i kao posljedica povrede ugovorne obveze. ${ }^{74}$ Ugovorna odgovornost svakako postoji u slučajevima kada pacijent s ljekarnikom sklapa ugovor o ljekarničkoj usluzi (npr. savjetovanje u odnosu na propisivanje ili pravilnu primjenu lijekova, medicinskih ili dijetetskih proizvoda) ${ }^{75}$ ili kupoprodajni ugovor (lijekovi, kozmetika, homeopatski pripravci) pa pri tome dođe do povrede prava osobnosti pacijenta (nedopuštenom obradom osobnih podataka pacijenta, njihovim uništenjem, gubitkom, izmjenom ili neovlaštenim otkrivanjem). Međutim, u ovim slučajevima dolazi do koincidiranja povrede ugovorne i povrede zakonske obveze, odnosno radi se i o građanskom deliktu. Na oštećeniku je izbor pravila na kojima će utemeljiti tužbeni zahtjev. U velikom broju slučajeva oštećenik će se opredijeliti za pravila deliktne odgovornosti. To može biti iz više zaloga, ali prije svega zbog pravila o duljini roka zastare i obujmu naknade štete. ${ }^{76}$

Ista je situacija i kod odgovornosti izvršitelja obrade za štetu koju počini voditelju obrade u izvršavanju obveza iz ugovora kojim se uređuje obrada osobnih podataka. U ovom se slučaju također može raditi o ugovornoj ili zakonskoj odgovornosti izvršitelja obrade. ${ }^{77} \mathrm{U}$ odnosu na vrstu štete koju je voditelju obrade prouzročio izvršitelj obrade, svojim činom ili propustom, može se raditi o imovinskoj šteti, ali i o neimovinskoj šteti. Obveza naknade neimovinske štete nastaje, na primjer, u slučaju da je ljekarni povrijeđeno pravo osobnosti na poslovni ugled i dobar glas zbog neovlaštenog otkrivanja, uništenja ili gubitka osobnih podataka pacijenta.

70 Čl. 28. GDPR-a.

71 Standardne ugovorne klauzule dopunjuju posebne pogodbe iz ugovora i imaju istu obvezujuću snagu. Obvezuju ugovornu stranu koja im pristupa samo ako su joj bile poznate ili joj morale biti poznate u vrijeme sklapanja ugovora. Klarić, P., Vedriš, M., op. cit. (bilj. 6), str. 407.

72 Voditelj i izvršitelj obrade mogu izabrati pojedinačni ugovor ili standardne ugovorne klauzule koje je ili izravno donijela Europska komisija ili ih je donijelo nadzorno tijelo. Recital 81. GDPR-a.

73 Recital 82. GDPR-a.

74 Kao razlog za prihvaćanje ugovorne odgovornosti za nematerijalnu štetu možemo istaknuti potrebu za povećanjem savjesnosti, pažnje i poštenja u ispunjavanju ugovornih obveza. Klarić, P., op. cit. (bilj. 60), str. 234.

75 Čl. 5. st. 1. toč. 4. ZOLJ-a.

76 Klarić, P., op. cit. (bilj. 60), str. 234.

77 Kao što je navedeno, čl. 28. GDPR-a navodi da izvršitelj obrade i voditelj obrade sklapaju ugovor koji uređuje predmet i trajanje obrade, prirodu i svrhu obrade, vrstu osobnih podataka i kategoriju ispitanika te obveze i prava voditelja obrade i izvršitelja obrade. Svakako da je moguća i odgovornost voditelja obrade prema izvršitelju obrade ukoliko je u konkretnoj situaciji povreda ugovorne obveze rezultat čina ili propusta voditelja obveze. 
U odnosu na obujam naknade neimovinske štete može se sa sigurnošću pretpostaviti da će se u praksi raditi o određivanju pravične novčane naknade kao oblika popravljanja. Pri tome, GDPR određuje da bi voditelj ili izvršitelj obrade trebao naknaditi svaku štetu koju osoba može pretrpjeti zbog obrade kojom se krši GDPR. Voditelj ili izvršitelj obrade trebao bi biti izuzet od odgovornosti ako dokaže da nije ni na koji način odgovoran za štetu. Pojam štete trebalo bi široko tumačiti s obzirom na sudsku praksu tako da se u potpunosti odražavaju ciljevi GDPR-a. Obrada kojom se krši GDPR također uključuje obradu kojom se krše provedbeni akti doneseni u skladu s GDPR-om i pravom države članice kojim se razrađuju pravila GDPR-a. Ispitanici bi trebali dobiti potpunu i učinkovitu naknadu za štetu koju su pretrpjeli. ${ }^{78}$

\subsection{Sudska nadležnost}

U odnosu na nadležnost sudova u postupcima za naknadu štete zbog povrede GDPR-a i ZPOUZP-a pri obradi osobnih podataka ispitanika, GDPR određuje da se nadležnost sudova države, u postupku za naknadu štete, određuje s obzirom na poslovni nastan, odnosno uobičajeno boravište, voditelja ili izvršitelja obrade. ${ }^{79}$ Pri tome, temeljem čl. 77. GDPR-a, možemo zaključiti da podnošenje pritužbe nadzornom tijelu, odnosno odlučivanje nadzornog tijela po pritužbi, ne predstavlja procesnu pretpostavku za pokretanje parnice za naknadu štete. ${ }^{80}$

\section{ZAKLJUČAK}

Ljekarnička djelatnost dočekuje primjenu GDPR-a u Republici Hrvatskoj s posebnim oprezom zbog njene opsežnosti, društvenog značaja i okolnosti da su zdravstveni podaci klasificirani kao posebno osjetljivi. Zbog toga će i ustanove i tvrtke koje obrađuju podatke o zdravlju biti pod posebnom paskom nadzornog tijela. Da bi se odstupanja od regulative otklonila, potrebno je napraviti dubinsku analizu postupka prilagodbe poslovne prakse, procjenu rizika i odgovornosti te odrediti potrebne mjere, alate i kadrovska rješenja.

Objekt zaštite GDPR-a jesu osobni podaci pojedinaca koji predstavljaju i sadržaj prava osobnosti, prije svega prava na privatnost osobnog i obiteljskog života. Potrebno je da ljekarne u svakodnevnom radu, s obzirom na to da imaju uvid u osobne podatke pacijenata, obraćaju pozornost na njihovu zaštitu, kako ne bi postali dostupni trećim osobama, te da ne dođe do slučajnog i nezakonitog uništenja, gubitka

78 Recital 146. GDPR-a.

79 Čl. 79. st. 2. GDPR-a.

80 Ne dovodeći u pitanje druga upravna ili sudska pravna sredstva, svaki ispitanik ima pravo podnijeti pritužbu nadzornom tijelu ako smatra da obrada osobnih podataka koja se odnosi na njega krši GDPR. Čl. 77. GDPR-a. 
i izmjene osobnih podataka, jer se u suprotnom izlažu postupcima za naknadu štete zbog povrede prava osobnosti korisnika.

Novost u ljekarnama, kao i u većini uslužnih djelatnosti, odnosi se na marketinške djelatnosti. Temeljem GDPR-a, korištenje osobnih podataka za obavijesti pacijentima o promotivnim akcijama u ljekarnama, putem elektroničke pošte ili unutar programa vjernosti, kako to nisu usluge od javnog interesa, podliježu obvezi dobivanja privole pacijenta. GDPR i ZPOUZP koriste pojam ,privola“ u značenju dobrovoljnog, posebnog, informiranog i nedvosmislenog izražavanja želja ispitanika, kojim on izjavom ili jasnom potvrdnom radnjom daje pristanak za obradu osobnih podataka što se na njega odnose. Ako se privola za upis osobnih podataka u bazu podataka vrši elektroničkim putem, treba istaknuti da istu vrijednost kao vlastoručan potpis ima samo kvalificirani elektronički potpis.

Odredbe u GDPR-u koje se odnose na odgovornost za štetu, ukazuju da se odgovornost osoba uključenih u obradu osobnih podataka (voditelj i izvršitelj obrade) procjenjuje temeljem pravila o subjektivnoj (kulpoznoj) odgovornosti, kod koje se krivnja štetnika predmnijeva. U slučajevima građanskopravne odgovornosti voditelja i izvršitelja obrade radi se o sudionicima obveznih odnosa, koji ispunjavaju obveze iz svoje profesionalne djelatnosti, te je potrebno da pri tome postupaju s povećanom pažnjom, prema pravilima struke i običajima (pažnjom dobrog stručnjaka). Odgovornost voditelja i/ili izvršitelja obrade je solidarna, a onaj štetnik koji podmiri puni iznos odštete za pretrpljenu štetu ima pravo na regresni zahtjev u odnosu na ostale voditelje i izvršitelje obrade. U odnosu na nadležnost sudova u postupcima za naknadu štete zbog povrede GDPR-a i ZPOUZP-a pri obradi osobnih podataka ispitanika, podnošenje pritužbe nadzornom tijelu, odnosno odlučivanje nadzornog tijela po pritužbi, ne predstavlja procesnu pretpostavku za pokretanje parnice za naknadu štete.

\section{LITERATURA}

\section{Knjige i članci:}

1. Gavella, N., Osobna prava I. dio, Pravni fakultet Sveučilišta u Zagrebu, Zagreb, 2000.

2. Gavella, N., ,Povreda prava na privatnost, posebno na vlastiti lik, glas, osobne zapise i pisma “, u: Klarić, P. (ur.). Odgovornost za neimovinsku štetu zbog povrede prava osobnosti. Narodne novine, Zagreb, 2006., str. 73-134.

3. Grundler Bencarić, A., GDPR: Trebaju li pacijenti ljekarnicima dati privolu za osobne podatke?, dostupno na: https://www.adiva.hr/adiva-ljekarne/rijec-farmaceuta/ gdpr-trebaju-li-pacijenti-ljekarnicima-dati-privolu-za-osobne-podatke/., stanje od 6. V. 2020.

4. Klarić P., Vedriš, M., Građansko pravo, Narodne novine, Zagreb, 2006.

5. Klarić, P., Odštetno pravo, Narodne novine, Zagreb, 2003.

6. Nikšić, S., Ugovor o zdravstvenoj usluzi, Pravni fakultet Sveučilišta u Zagrebu, doktorska disertacija, Zagreb, 2007. 
7. Nova verzija programa ESKULAP 2000 Verzija 3.4 .5 - početak primjene GDPR-a, Information Systems, 2019., dostupno na: http://www.i-s.hr/default. aspx?ContentId=802., stanje od 6. V. 2020.

8. Radmilović, Ž., „Biometrijska identifikacija“, Policija i sigurnost, Vol. 17, No. 3-4, Zagreb, 2008., str. 159-180.

9. Wardle, N., Reissner, D., „How pharmacists can coply with GDPR“, The Pharmaceutical Journal, 2018., dostupno na: https://www.pharmaceuticaljournal.com/cpd-and-learning/learning-article/how-pharmacists-can-comply-withgdpr/20204872.article? firstPass=false., stanje od 6. V. 2020.

\section{Pravni izvori:}

1. Article 29 Data Protection Working Party, Statement on the 2016 action plan for the implementation of the General Data Protection Regulation (GDPR) - 442/16/ ENWP236, dostupno na: https://ec.europa.eu/newsroom/article29/item-detail. cfm?item_id=640360, stanje od 6. V. 2020.

2. Ec.europa.eu. Working Document 01/2016 on the justification of interferences with the fundamental rights to privacy and data protection through surveillance measures when transferring personal data (European Essential Guarantees), dostupno na: https://ec.europa.eu/newsroom/article29/item-detail.cfm?item_id=640363/, stanje od 6. V. 2020.

3. Europska konvencija za zaštitu ljudskih prava i temeljnih sloboda, NN - Međunarodni ugovori, br. 18/97, 6/99, 14/02, 13/03, 9/05, 1/06, 2/10.

4. Uredba (EU) 2016/679 Europskog parlamenta i Vijeća od 27. travnja 2016. o zaštiti pojedinaca u vezi obradom osobnih podataka i o slobodnom kretanju takvih podataka te o stavljanju izvan snage Direktive 95/46/EZ (Opća uredba o zaštiti podataka), SL L119/1 od 4. V. 2016., dostupno na: https://eur-lex.europa.eu/legal-content/HR/TXT/ PDF/?uri=CELEX:32016R0679\&from=EN, stanje od 6. V. 2020.

5. Uredba (EU) br. 910/2014 Europskog parlamenta i Vijeća od 23. srpnja 2014. o elektroničkoj identifikaciji i uslugama povjerenja za elektroničke transakcije na unutarnjem tržištu i stavljanju izvan snage Direktive 1999/93/EZ, SL L 257/73 od 28. 8. 2014., dostupno na: https://eur-lex.europa.eu/legal-content/HR/ TXT/?uri=CELEX\%3A32014R0910, stanje od 6. V. 2020.

6. Ustav Republike Hrvatske, NN, br. 56/90, 135/97, 8/98, 113/00, 124/00, 28/01, 41/01, 55/01, 76/10, 85/10, 05/14.

7. Zakon o ljekarništvu, NN, br. 121/03, 142/06, 35/08, 117/08.

8. Zakon o obveznim odnosima, NN, br. 35/05, 41/08, 125/11, 78/15, 29/18.

9. Zakon o provedbi Opće uredbe o zaštiti podataka, NN, br. 42/18.

10. Zakon o zaštiti na radu, NN, br. 71/14, 118/14, 154/14, 94/18, 96/18. 


\section{CIVIL LAW ASPECTS OF GENERAL DATA PROTECTION REGULATION (GDPR) IN THE CONDUCTION OF PHARMACY PRACTICE}

Since its entry into force, it was possible to get the impression that the addressees were expecting GDPR implementation unprepared. The paper will highlight the problems that have arisen in harmonizing pharmacy practices with GDPR requirements. The provisions of the GDPR, relating to the presumptions for the validity of a informed consent for the processing of personal dana, correspond to the requirements for the validity of the informed consent in the contemporary legal orders. If the enrollment of personal data in the database is done electronically, it should be noted that the same value as self-signed signature has only a qualified electronic signature. The GDPR provisions relating to liability for damage indicate that the responsibility of persons involved in the processing of personal data (controller and processor) is assessed under the rules of subjective liability. The question also arises whether filing a complaint to a supervisory authority, or not resolving a competent body on a complaint, is a procedural precondition for bringing an action for damages before a competent court.

Key words: regulation, pharmacy, general data, personality rights, consent 